\title{
KIRJOITUS
}

LAURA KALLATSA

\section{Suomen evankelis-luterilaisen kirkon pappien käsitykset samaa sukupuolta olevien avioliitosta ja asenteet homoseksuaalisuutta kohtaan}

\begin{abstract}
$\Lambda$ lkusyksyn 2020 aikana on keskusteltu paljon ykseydestä. Suomen evankelis-luterilaisen kirkon kirkolliskokous kokoontui elokuussa $2020 \mathrm{Tu}$ russa, jossa se käsitteli muun muassa piispainkokouksen vastausta kysymykseen samaa sukupuolta olevien avioliitosta. Kymmensivuisessa asiakirjassaan piispat puhuvat paljon ykseydestä, siitäkin huolimatta, että piispakunta vaikuttaa kirkkoa ravisuttavassa avioliittokysymyksessä varsin jakaantuneelta. Piispat kirjoittavat, että kirkon ja kristittyjen ykseys ei ole valinta, vaan todellisuus, jonka Jumala lahjoittaa kirkolle. Piispojen mukaan ykseyden ehto tai tavoite ei ole kirkon jäsenten yhdenmukaisuus, vaan jakaantumisen ja hajaannuksen välttäminen. Näin ollen kirkon ykseyden ei ole tarkoituskaan perustua täydelliselle samanmielisyydelle, vaan yhteiseen uskoon. (Piispainkokouksen vastaus, 2020.)

Piispat toteavat, että kirkon historia on ykseyden koettelun historiaa. Ykseyttä on koeteltu ja sitä kohti on pyritty myös kirkon lähihistoriassa keskusteltaessa perheeseen, parisuhteisiin ja seksuaalisuuteen liittyvistä kysymyksistä. Etenkin samaa sukupuolta olevien avioliitto on noussut 2000-luvun
\end{abstract}


ensimmäisten vuosikymmenten näkyväksi keskustelunaiheeksi Suomen evankelis-luterilaisessa kirkossa. Äänenpainot vahvistuivat jo keskusteltaessa vuonna 2002 voimaan tulleen rekisteröidyn parisuhteen vaikutuksista kirkkoon, eivätkä ne ole ainakaan vaienneet vuonna 2017 voimaan astuneen uuden avioliittolain myötä.

Kirkossa on otettu kantaa samaa sukupuolta olevien avioliittoon monissa yhteyksissä. Kirkon ylimmät päättävät elimet kirkolliskokous ja piispainkokous ovat linjanneet, että kirkossa ei vihitä samaa sukupuolta olevia pareja avioliittoon. Niiden mukaan avioliitto ymmärretään kirkossa miehen ja naisen väliseksi liitoksi. (Yleisvaliokunnan mietintö 3/2015:18-19; Piispainkokouksen selonteko avioliittolain muutoksen johdosta 2016:1-2.) Samaan aikaan yksittäiset piispat ovat antaneet toisistaan poikkeavia lausuntoja siitä, miten kirkossa tulisi toimia tilanteessa, jossa yhteiskunnan avioliittolaki sallii samaa sukupuolta olevien avioliittoon vihkimisen. Niin ikään kirkossa työskentelevät papit ovat tuoneet julkisesti esiin omia avioliittokantojaan ja yksittäisissä seurakunnissa on annettu toisistaan poikkeavia linjauksia esimerkiksi siitä, rukoillaanko seurakunnan jumalanpalveluksessa samaa sukupuolta olevien avioparien puolesta ja ovatko seurakuntien tilat avoinna kaikille avioliittoon vihittäville pareille.

Kirkon virallisesta linjauksesta huolimatta kirkossa on nyt jo yli kolmen vuoden ajan vihitty samaa sukupuolta olevia pareja avioliittoon. Useat kymmenet itseään sateenkaaripapeiksi kutsuvat papit ovat julkisesti ilmoittaneet olevansa valmiita vihkimään samaa sukupuolta olevia pareja. Papilla on avioliittoon vihkijänä kaksoisrooli: vihkiessään hän on sekä valtion virkamies että kirkon edustaja. Näin ollen kirkollisesti solmitut samaa sukupuolta olevien avioliitot ovat juridisesti päteviä, vaikkakin vastoin kirkon virallista avioliittokäsitystä.

Suomessa ja Suomen evankelis-luterilaisessa kirkossa on kuljettu monivaiheinen ja monen mielestä pitkä tie tähän pisteeseen, jossa osa avioliiton samaa sukupuolta olevan puolison kanssa solmineista on viettänyt kirkkohäitä. Toiset taas kokevat, että muutokset ovat tapahtuneet liian nopeasti tai että muutoksia ei olisi pitänyt tapahtua ollenkaan. Joka tapauksessa suomalaisten ja Suomen evankelis-luterilaisen kirkon jäsenten ja työntekijöiden asenteet ovat muuttuneet huomattavasti nopeammin kuin kirkon viralliset linjaukset.

Homoseksuaalisuuteen ja samaa sukupuolta olevien parisuhteisiin liittyvä asenteiden muutos ei ole vain suomalainen ilmiö. Länsimaissa asenteet 
seksuaali- ja sukupuolivähemmistöjä kohtaan ovat muuttuneet huomattavasti hyväksyvämmiksi viimeisten vuosikymmenten aikana. Tämä kansainvälisesti tunnettu seksuaali- ja perhearvojen murros on vaikuttanut laajasti myös eri kristillisissä kirkkokunnissa. Useiden kansainvälisten tutkimusten mukaan seksuaalivähemmistöihin kuuluvien ihmisten hyväksyntä seurakunnissa on kasvanut huomattavasti. Kuitenkin eri kristillisten traditioiden välillä on suuria eroja siinä, miten esimerkiksi homoseksuaalisuuteen suhtaudutaan. Protestanttisissa seurakunnissa homoseksuaalisuuteen suhtaudutaan yleensä kaikista hyväksyvimmin. Pohjoismaissa ja pohjoismaisissa luterilaisissa kirkoissa homoseksuaalisuuteen ja samaa sukupuolta olevien parisuhteisiin suhtaudutaan kansainvälisesti tarkasteltuna hyväksyvästi. (Esim. Cadge ym., 2012; Whitehead, 2013; Cragun ym., 2015; Kirby ym., 2017.)

Myös Suomen evankelis-luterilaisen kirkon pappien asenteet homoseksuaalisuutta ja samaa sukupuolta olevien parisuhteita kohtaan ovat muuttuneet hyväksyvämmiksi koko 2000-luvun ajan. Vuonna 200638 prosenttia papeista toivoi mahdollisuutta saada rekisteröidylle parisuhteelle kirkollinen siunaus. Vuonna 201857 prosenttia papeista kannatti samaa sukupuolta olevien avioliittoon vihkimistä. Pappien asenteita on tutkittu Kirkon akateemisten jäsenkyselyissä useaan otteeseen 2000-luvun aikana. (Niemelä \& Palmu, 2006; Niemelä, 2010; Tervo-Niemelä, 2018; Kallatsa \& Kiiski, 2019.) Samaa sukupuolta olevien avioliittoa kiivaasti kannattavat tai sitä vastustavat papit ovat saaneet äänensä kuuluville näkyvästi myös mediassa.

Suuresta näkyvyydestä huolimatta aiheeseen liittyvät, kirkon näkökulmastakin oleelliset, argumentit ovat usein jääneet piiloon tai tulleet yksipuolisesti esille. Väitöskirjassani olen selvittänyt sitä, miten papit perustelevat omia näkemyksiään (Kallatsa, 2020). Paine avioliittokäsityksen uudelleen arviointiin on noussut niin kirkon ulkopuolelta kuin sisältäkin. Luterilainen kirkko on kansankirkko ja Suomessa on totuttu siihen, että kirkon ja yhteiskunnan avioliittokäsitykset näyttäytyvät ulkoisesti samankaltaisina. Kirkko on kuitenkin halunnut vastata kysymykseen samaa sukupuolta olevien avioliittoon vihkimisestä omista lähtökohdistaan.

Väitöskirjani tavoitteena oli selvittää, millaisia käsityksiä ja perusteluja papeilla on samaa sukupuolta olevien parisuhteista. Ensiksikin tutkin sitä, miten papit kuvaavat asennemuutostaan homoseksuaalisuutta kohtaan viimeisen kymmenen vuoden aikana ja mitkä tekijät ovat vaikuttaneet muutokseen. Toiseksi tutkin, millaisia käsityksiä papeilla on samaa sukupuolta olevien 
avioliittoon vihkimisestä siviilivihkimisenä ja kirkollisena vihkimisenä ja miten he perustelevat käsityksiään. Kolmanneksi tutkin sitä, millaisia käsityksiä papeilla on samaa sukupuolta olevien avioliiton siunaamisesta ja miten he perustelevat näitä käsityksiään.

Tutkin pappien asenteita ja käsityksiä. Tutkimuksessani tukeudun Gordon Allportin (1958) esittämään asenteen määritelmään. Hänen mukaansa asenne on opittu taipumus ajatella, tuntea ja käyttäytyä erityisellä tavalla tiettyä kohdetta kohtaan. Käsitys puolestaan tarkoittaa tutkimuksessani jotakin sellaista, jonka tutkija muodostaa tutkimusaineiston pohjalta. Tehtäväni tutkijana on ollut luoda kokonaisuus pappien antamista kielellisistä ilmauksista ja muodostaa niiden pohjalta käsitteitä, jotka kuvaavat pappien käsityksiä samaa sukupuolta olevien avioliittoon vihkimisestä ja avioliiton siunaamisesta.

Tutkimusaineistoni on kerätty sähköisellä kyselylomakkeella keväällä 2017, juuri samoihin aikoihin kuin uusi avioliittolaki tuli Suomessa voimaan. Aineisto koostuu 534 Suomen evankelis-luterilaisen kirkon papin vastauksesta. Aineisto edustaa hyvin Suomen evankelis-luterilaisen kirkon pappeja muun muassa sukupuoli- ja hiippakuntajakaumaa tarkasteltaessa. Olen käsitellyt tutkimusaineistoani monimenetelmäisesti. Päämetodi on laadullinen sisällönanalyysi, jota tukevat määrälliset tutkimusmenetelmät. Näin ollen tutkimukseni antaa ensisijaisesti vastauksia siihen, miten papit perustelevat omia homoseksuaalisuuteen ja samaa sukupuolta olevien avioliittoon liittyviä näkemyksiään. Tutkimukseni ensisijainen tarkoitus ei ole pyrkiä yleistettävyyteen, mutta koska aineistoni on määrällisesti niin suuri, 534 papin vastaukset, aineistoa on ollut mielekästä käsitellä myös numeerisesti. Tutkimukseni antaa luotettavia suuntaviivoja sille, millaiset asenteet ja käsitykset ovat papeille ominaisia.

Kuviossa 1 on kuvattu pappien käsitykset samaa sukupuolta olevien avioliiton siunaamisesta ja avioliittoon vihkimisestä. Keskellä olevissa laatikoissa ovat tutkimusaineistosta muodostetut neljä argumenttikategoriaa. Papit perustelevat avioliiton siunaamiseen ja avioliittoon vihkimiseen liittyviä käsityksiään teologisilla, ihmisoikeudellisilla ja muilla juridisilla, avioliiton olemukseen ja käsitteeseen liittyvillä sekä papin työhön ja kirkon päätöksiin liittyvillä perusteluilla. Vasemmalla puolella on avioliiton siunaamiseen ja avioliittoon vihkimiseen liittyvät vastustavat argumentit ja oikealla kannattavat argumentit. Nuolen suuruus kertoo siitä, kuinka yleinen kyseinen argumenttikategoria tutkimuksessani on. Huomattavaa on, että tutkimusaineistossani papit perus- 


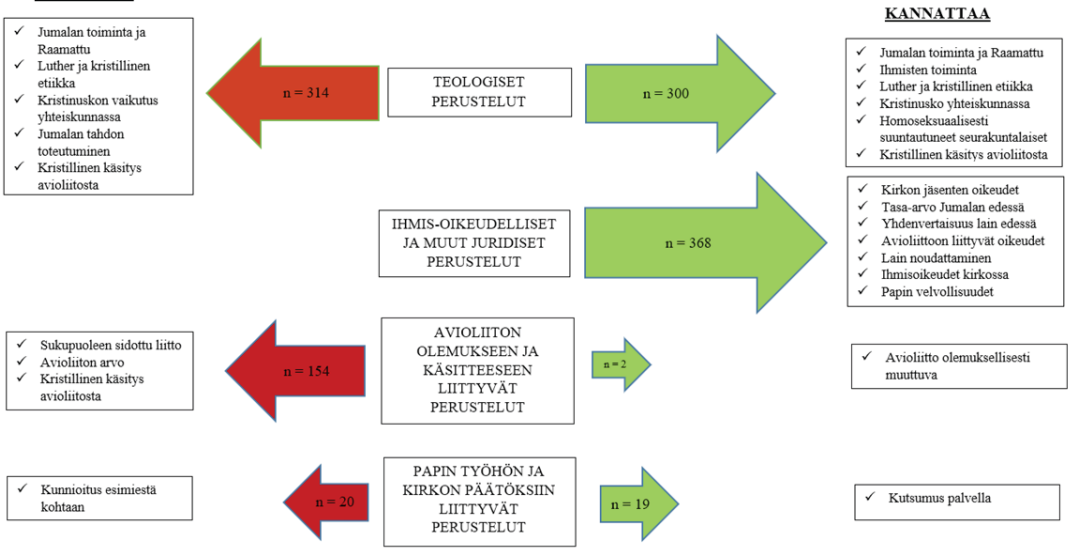

Kuvio 1. Pappien käsitykset samaa sukupuolta olevien avioliitosta.

televat avioliittoon liittyviä käsityksiään selvästi useimmiten teologisilla argumenteilla.

Pappien avioliittokäsitysten taustalla vaikuttavat voimakkaasti heidän asenteensa homoseksuaalisuutta kohtaan. Useampi kuin joka kolmas papeista kertoo, että heidän asenteensa homoseksuaalisuutta kohtaan ovat muuttuneet viimeisen kymmenen vuoden aikana. Valtaosa niistä papeista, joiden asenteissa on tapahtunut muutosta, kertoo asenteidensa muuttuneen aikaisempaa ymmärtäväisemmiksi ja hyväksyvämmiksi.

Samaa sukupuolta olevien avioliitto on kirkolle haastava kysymys. Sen osoittavat niin väitöskirjani tulokset kuin kirkossa jo pitkään käyty - ja alati jatkuva - keskustelu avioliitosta. Kuten alussa toin esille, viimeisten viikkojen aikana piispat ovat korostaneet pyrkimystä ykseyteen. Piispojen mukaan kirkossa tulevaisuutta rakennetaan uskon, opin ja elämän pohjalta. Tutkimukseni avaa juuri näitä kolmea: uskoa, oppia ja elämää kirkon työntekijöiden, pappien näkökulmasta.

Samaa sukupuolta olevien avioliitto ei ole marginaalinen kysymys kirkossa. Se ei kosketa vain pientä ihmisryhmää ja heidän lähipiiriään, vaan liittyy 
vahvasti uskoon, oppiin ja ennen kaikkea elämään. Samaa sukupuolta olevien avioliitto liittyy laajasti siihen, millainen on kirkon ihmiskäsitys, millainen on sen käsitys seksuaalisuudesta ja sukupuolesta, miten kirkossa luetaan ja tulkitaan Raamattua ja traditiota, miten kirkko asemoituu suhteessa yhteiskunnassa säädettyihin lakeihin ja mikä kirkon avioliittoteologiassa on muuttumatonta ja mikä muuttuvaa.

\section{Lectio Praecursoria Itä-Suomen yliopistossa 4.9.2020}

\section{Kirjallisuus}

Allport, G. W. (1958). The Nature of Prejudice. Reading, MA: Addison-Wesley.

Cadge, W. \& Girouard, J. \& Olson, L. \& Lylerohr, M. (2012). Uncertainty in clergy's perspectives on homosexuality: A research note. Review of Religious Research, 54(3), 371-387. https://doi.org/10.1007/ s13644-012-0058-1

Cragun, R. T. \& Sumerau, J. E. \& Willias, E. (2015). From sodomy to sympathy: Lds elite's discursive construction of homosexuality over time. Journal for the Scientific Study, 54(2), 291-310. https://doi. org/10.1111/jssr.12180

Kallatsa, L. (2020). Homoseksuaalisuus ja papit - Suomen evankelis-luterilaisen kirkon pappien käsitykset samaa sukupuolta olevien avioliitosta ja asenteet homoseksuaalisuutta kobtaan. Itä-Suomen yliopisto: Dissertations in Education, Humanities, and Theology, No 156.

Kallatsa, L. \& Kiiski, J. (2019). Vibkiäkö vai ei? Suomen evankelis-luterilaisen kirkon pappien käsitykset samaa sukupuolta olevien oikeudesta kirkolliseen avioliittoon. Kirkon tutkimuskeskuksen verkkojulkaisuja 60 .

Kirby, A. \& Mckenzie-Green, B. \& Mcara-Couper, J. \& Nayar, S. (2017). Same-sex marriage: a dilemma for parish clergy. Sexuality and Culture, 21(3), 901-918. https:// doi.org/10.1007/s12119-017-9414-1

Niemelä, K. \& Palmu. H. (2006). Papisto ja kanttorit 2006. Akavan kirkollisten ammattiliittojen jäsenkyselyjen raportti. Kirkon tutkimuskeskuksen www-julkaisuja 11.

Niemelä, K. (2010). Papisto ja kanttori 2010. Akavan kirkollisten ammattijärjestöjen jäsenkyselyn raportti. Kirkon tutkimuskeskuksen www-julkaisuja 20.

Piispainkokouksen selonteko avioliittolain muutoksen johdosta (2016). https://evl. fi/documents/1327140/9823846/PK+VALMIS+AVIOLIITTOSELONTE$\mathrm{KO}+2016$.pdf/c1bb8df3-7b77-404ab05a-f5582b219a36 - Viitattu 25.9.2020.

Piispainkokouksen vastaus (2020). Piispainkokouksen vastaus kirkolliskokouksen pyyntöön. https://evl.fi/ documents/1327140/74688669/piispainkokouksen-vastaus-kirkolliskokouksen-pyyntoon-20200806.pdf - Viitattu 25.9.2020.

Tervo-Niemelä, K. (2018). Kutsumuksen imu ja työn todellisuus. Pappien, teologien ja kanttoreiden subde työhön, työhyvinvointi ja subtautuminen ajankohtaisiin kysymyksiin Kirkon akateemisten jäsentutkimuksessa 2018. Kirkon tutkimuskeskuksen verkkojulkaisuja 58.

Whitehead, A. L. (2013). Religious organizations and homosexuality: the acceptance of gays and lesbians in american congregations. Review of Religious Research, 55(2), 297-317. https://doi.org/10.1007/ s13644-012-0066-1

Yleisvaliokunnan mietintö (2015). Mietintö 3/2015 edustaja-aloitteesta 2/2015. Uusi avioliittolaki. 